\title{
Rannveig Sigurvinsdóttir
}

\section{„Pú veist pú vilt pað“}

\section{Skýringar á kynferðisofbeldi á samfélagsmiðlum}

Barátta gegn kynferðisafbrotum og umræða um pau hefur aukist jafnt og pétt í íslensku samfélagi. Nærtækt er að minnast hreyfinga sem kenndar hafa verið við Beauty tips og \#MeToo. Alpjóða heilbrigðismálastofnunin (e. World Health Organization) hefur skilgreint kynferðisofbeldi sem kynferðislega hegðun (eða tilraun til hennar), kynferðislega tilburði eða athugasemdir gegn vilja viðkomandi með pví að nota einhvers konar pvingun, óháð sambandi geranda og polanda og óháð staðsetningu. ${ }^{1}$ Rannsóknir síðustu ára sýna að slíkt ofbeldi á sér stað hérlendis, en til dæmis leiddi ein rannsókn frá 2010 í ljós að 24\% kvenna á aldrinum 18-80 ára höfðu sætt kynferðisofbeldi af hendi karlmanns einhvern tíma eftir að pær urðu 16 ára gamlar. ${ }^{2}$ Afleiðingar ofbeldisins geta verið alvarlegar, meðal annars aukin hætta á áfallastreituröskun, punglyndi og sjálfsvígi. ${ }^{3}$ Til dæmis sýndi rannsókn meðal íslenskra framhaldsskólanema að einkenni kvíða, punglyndis og reiði voru hærri meðal polenda kynferðisofbeldis, auk

1 Alpjóðaheilbrigðismálastofnunin, World Health Report, sótt 24. júlí 2018 af http://www.who.int/violence_injury_prevention/violence/global_campaign/en/ chap6.pdf, hér bls. 149.

2 Í pessari rannsókn var kynferðisofbeldi skilgreint sem pvingun eða tilraun til samfara með ofbeldi eða hótun, kynferðisleg snerting sem veldur vanlíðan, svo og aðrar tegundir kynferðisofbeldis. Elísabet Karlsdóttir og Ásdís A. Arnalds, „Rannsókn á ofbeldi gegn konum: Reynsla kvenna á aldrinum 18-80 ára á Íslandi“, Stjórnarrádið, desember 2010, sótt 29. apríl 2018 af https://www.stjornarradid.is/media/ velferdarraduneyti-media/media/ritogskyrslur2011/26012011_Ofbeldi_a_konum. pdf, hér bls. 27.

3 Elizabeth O. Paolucci, Mark L. Genuis og Claudio Violato, „A meta-analysis of the published research on the effects of child sexual abuse", The Fournal of Psychology, 135/2001, bls. 17-36, hér bls. 17; Emily R. Dworkin, Suvarna M. Menon, Jonathan Bystrynski og Nicole Allen, „Sexual assault victimization and psychopathology: A review and meta-analysis“, Clinical Psychology Review, 56/2017, bls. 65-81, hér bls. 65. 
sjálfsskaðandi hegðunar og sjálfsvígshegðunar. ${ }^{4}$ Algengast er að polendur ofbeldisins séu konur og karlar gerendur pó vissulega séu dæmi um annað. ${ }^{5}$

Lengi vel var lítið rætt opinberlega um efnið en miklu skiptir að í samfélaginu sé fólk almennt á einu máli um að nauðganir og aðrar kynferðispvinganir séu ekki líðandi fremur en annað ofbeldi. Síðustu ár hafa polendur hinsvegar verið hvattir til að segja frá reynslu sinni til að vinna gegn pöggun um málaflokkinn. Afstaða löggjafans og dómsvaldsins til kynferðisbrota hafa enda breyst síðustu ár, til dæmis með endurskoðun lagaákvæða um kynferðisbrot og pyngingu dóma. ${ }^{6}$ Samfélagsmiðlar eru áhugaverðir og aðgengilegir til að miðla reynslu og skoðunum og margir polendur hafa nýtt pá til að segja frá eigin upplifun. Birting polenda á eigin sögum kann líka að gefa rödd peirra annað vægi en pegar sagt er frá í eigin persónu eða á öðrum miðlum. ${ }^{7}$ Tilgangur pessarar eigindlegu rannsóknar, sem hér verður greint frá, er að lýsa skýringum á kynferðisofbeldi sem eru settar fram á samfélagsmiðlum og kanna hvort pær ríma við fyrri rannsóknir á pessu sviði. Slíkar skýringar eru mikilvægar bví pær varpa ljósi á samfélagslegt samhengi, p.e. hvað fólki finnist að valdi pví að ofbeldi eigi sér stað, sem endurspeglar svo sýn peirra um hvað mætti gera til að koma í veg fyrir slíkt ofbeldi. Petta verður gert með pví að skoða færslur á samfélagsmiðlum par sem polendur segja frá eigin reynslu af slíku ofbeldi. Skýring á ofbeldi er nokkuð vítt hugtak en felur í grunninn í sér einhvers konar eignun (e. attribution), p.e. að einhver páttur er notaður til að útskýra af hverju ofbeldið átti sér stað. Ekki er nauðsynlegt að um sé að ræða raunverulega orsakapætti, heldur endurspeglar petta sýn viðkomandi á fyrirbærið.

4 Bryndís Björk Ásgeirsdóttir, „Kynferðislegt ofbeldi gegn börnum sem áhættupáttur tilfinninga- og hegðunarvandamála“, Hinn launhelgi glepur: Kynferðisbrot gegn börnum, ritstj. Svala Ísfeld Ólafsdóttir, Reykjavík: Háskólaútgáfan, 2011, bls. 269-295, hér bls. 269-270.

5 Extent, nature and consequences of rape victimization: Findings from the national violence against women survey, National Institute of Justice í Bandaríkjunum, 2006, sótt 1. nóvember 2018 af https://www.ncjrs.gov/pdffiles1/nij/210346.pdf, hér bls. 7-12.

6 Svala Ísfeld Ólafsdóttir, „Refsiákvæði sem varða kynferðisbrot gegn börnum“, Hinn launhelgi glepur: Kynferð̌isbrot gegn börnum, ritstj. Svala Ísfeld Ólafsdóttir, Reykjavík: Háskólaútgáfan, 2011, bls. 57-108, hér bls. 60-61; Ragnheiður Bragadóttir, „Próun refsinga fyrir kynferðisbrot“, Stjórnmál og stjórnsýsla 5: 1/2009, bls. 49-68, hér 61-63.

7 Timothy D. Wilson, Elliot Aronson og Kevin Carlsmith, „The art of laboratory experimentation“, Handbook of Social Psychology, ritstj. Susan T. Fiske, Daniel T. Gilbert og Gardner Lindzey, Hoboken NJ: Wiley, bls. 51-81. 
Fáar rannsóknir eru til um petta efni, en í erlendum rannsóknum hafa skýringar gerenda á ofbeldi verið kannaðar til að meta hvað fær pá til að brjóta á öðrum. Til dæmis hafa rannsakendur tekið viðtöl við dæmda nauðgara sem sitja inni fyrir brot $\sin ^{8}$ og ónafngreindir gerendur hafa sett fram sínar eigin sögur á netinu. ${ }^{9}$ Útskýringar og réttlætingar gerendanna varpa ljósi á sýn peirra, en pær eru einnig mikilvægar af pví að peir sem réttlæta brot sitt eru líklegri til að fremja annan kynferðisglæp innan árs. ${ }^{10}$ Skýringarnar sem gerendurnir gefa eru fjölbreyttar en algengt er að polendum sé kennt um ofbeldið, til dæmis að peir hafi dregið gerandann á tálar og skipt um skoðun seinna, eða að áfengisneyslu polanda sé um að kenna. Par að auki taka gerendaskýringar mið af útbreiddum samfélagslegum viðhorfum til samskipta kynjanna og kynlífs, eins og að karlar purfi að eiga frumkvæði að kynlífi og að konur segi nei við kynlífi en meini í raun já. ${ }^{11}$

Erlendar rannsóknir á skýringum polenda á kynferðisofbeldi hafa hins vegar skilað sundurleitum niðurstöðum. Árið 2014 leiddi ein slík rannsókn meðal kvenkyns háskólanema í Bandaríkjunum í ljós að polendur kynferðisofbeldis kenndu gerendunum sjálfum oftast um ofbeldið. ${ }^{12}$ Rannsókn frá 2017 á svipuðum hópi sýndi aftur á móti að polendur nauðgana kenndu oftast sjálfum sér og samfélaginu um glæpinn, einnig teldu peir ástæðuna vera sérstakar aðstæður, en athyglisverðast var að peir kenndu gerandanum sjaldnast um, raunar sögðu 52\% pátttakenda að ofbeldið væri alls ekki gerandanum að kenna. ${ }^{13}$

8 Anthony R. Beech, Tony Ward og Dawn Fisher, „The identification of sexual and violent motivations in men who assault women: Implication for treatment", Sex Roles, 72: 11-12/2006, bls. 1635-1653, hér bls. 1638-9.

9 Tracy N. Hipp, Alexandra L. Bellis, Bradley L. Goodnight, Carolyn L. Brennan, Kevin M. Swartout og Sarah L. Cook, „Justifying sexual assault: Anonymous perpetrators speak out online“, Psychology of Violence, 7: 1/2017, bls. 82-90, hér bls. 82.

10 Rhiana Wegner, Antonia Abbey, Jennifer Pierce, Sheri E. Pegram og Jacqueline Woerner, „Sexual assault perpetrators' justifications for their actions: Relationships to rape supportive attitudes, incident characteristics, and future perpetration", Violence Against Women, 21: 8/2015, 1018-1037, hér bls. 1018.

11 Anthony R. Beech o.fl., "The identification of sexual and violent motivations in men who assault women: Implication for treatment", bls. 1635; Tracy N. Hipp o.fl., „Justifying sexual assault: Anonymous perpetrators speak out online“, bls. 84-87.

12 Carin Perilloux, Joshua D. Duntley og David M. Buss, „Blame attribution in sexual victimization“, Personality and Individual Differences, 63/2014, bls. 81-86, hér bls. 83.

13 Sapanda D. Donde, „College women's attributions of blame for experiences of 
Rannsóknir á skýringum ofbeldis eru oftast gerðar með tvennum hætti: Með pví að taka viðtöl eða leggja spurningalista fyrir gerendur eða polendur. Aðferðirnar hafa sína kosti og galla, par sem viðtöl leyfa djúpa greiningu á litlum hópi en með notkun spurningalista má safna tölulegum gögnum frá stórum hópi. Sýn rannsakandans á viðfangsefnið mótar um hvað er spurt og hvernig, en viðtöl bjóða upp á meiri sveigjanleika hvað petta varðar. Samfélagsmiðlar hafa opnað nýja leið til að rannsaka skýringar á ofbeldi, par sem mikið efni hefur verið gert opinbert sem fjallar um upplifanir, skoðanir og tilfinningar fólks. Kosturinn er að færslurnar koma beint frá viðkomandi aðilum án milligöngu fræðimanna. Petta skiptir máli af pví að samfélagsumræðan um ofbeldi ætti ekki aðeins að fara fram milli fræðimanna, heldur einnig meðal almennings og pá sérstaklega peirra sem hafa persónulega reynslu af málaflokknum. Rannsóknir á samfélagsmiðlum geta líka auðveldað rannsóknir á viðkvæmum viðfangsefnum pví pær fela yfirleitt í sér minna inngrip fyrir pátttakendur. ${ }^{14}$ Líkt og með aðrar rannsóknir mótar sýn fræðimanna pó pessa tegund gagna á einhvern hátt, pví merking er lesin út úr færslunum sjálfum. Fyrsta rannsókn pessarar tegundar kom út árið 2017 og skoðaði frásagnir gerenda kynferðisofbeldis sem peir birtu nafnlaust á síðunni Reddit. ${ }^{15}$ Auglýst var eftir sögum gerenda og spurt hvað hefði vakað fyrir peim og hvort peir sæju eftir að hafa brotið á öðrum. Rannsakendur greindu skýringar og réttlætingar í 68 sögum gerenda og komust að pví að pær sneru yfirleitt að samfélaginu eða polandanum, ekki að gerandanum sjálfum.

Rannsóknin sem hér verður greint frá er sú fyrsta hérlendis sem skoðar skýringar á ofbeldi og sú fyrsta í heiminum sem nýtir sér gögn frá polendum kynferðisofbeldis af samfélagsmiðlum til pess (svo höfundur viti til). ${ }^{16}$ Rannsóknin byggir á íslenskum færslum sem polendur kynferðis-

sexual assault“, Journal of Interpersonal Violence, 32: 22/2017, bls. 3520-3538, hér bls. 3527 .

14 Timothy D. Wilson, Elliot Aronson og Kevin Carlsmith, „The art of laboratory experimentation“, Handbook of Social Psychology, ritstj. Susan T. Fiske, Daniel T. Gilbert og Gardner Lindzey, Hoboken NJ: Wiley, bls. 51-81.

15 Reddit.com er vefsíða par sem notendur setja inn fréttir, myndir og fleira og aðrir geta komið með viðbrögð og athugasemdir. Í febrúar 2018 voru 542 milljón heimsókna á síðuna (sbr. https://en.wikipedia.org/wiki/Reddit). Sjá grein um skýringar gerenda í Tracy N. Hipp o.fl., „Justifying sexual assault: Anonymous perpetrators speak out online“, bls. 82 .

16 Fjölbreyttar rannsóknir á samfélagsmiðlum eiga sér stað um allan heim, til dæmis til að skoða kosningahegðun fólks í samhengi við nýtingu á samfélagsmiðlum. Einnig hafa sumir rannsakendur skoðað frásagnir af netinu um kynferðisofbeldi og við- 
ofbeldis hafa skrifað á Twitter og Facebook um upplifun sína. Markmið rannsóknarinnar var að varpa ljósi á skýringar sem koma fram í færslum polendanna og bera pær saman við fyrri rannsóknir. Gögnin eru fjölbreytt par sem polendur segja frá eigin upplifun og áhrifum ofbeldisins. Í sumum tilvikum vísa polendur beint í ákveðna pætti sem skýringu ofbeldisins en lýsa einnig aðstæðum, hegðun gerandans og viðbrögðum annarra. Lýsingar í frásögnum polandans eru mikilvægar í pessu samhengi par sem frásögn polandans er sjálfsprottin, p.e. ekki svar við ákveðinni spurningu. Upplýsingarnar sem koma fram markast pannig af pví sem viðkomandi finnst sjálfum mikilvægt og vill að aðrir viti. Rannsóknir í félagssálfræði hafa sýnt að fólk hefur ríka pörf fyrir að leita að dýpri merkingu og skýringum á eigin upplifunum. Frásagnir og lýsingar af atburðum endurspegla pannig gjarnan pætti sem skýra pá. Til dæmis er klassísk tilraun í sálfræði að biðja pátttakendur að lýsa myndbandi af príhyrningi, kassa og hring sem færast um skjá á ákveðinn hátt. Prátt fyrir að aðeins sé beðið um lýsingar gefa pátttakendur nær undantekningarlaust skýringar á hreyfingunum og gefa jafnvel dauðum hlutum ætlun (t.d. að eitt formið sé að stríða hinum). ${ }^{17}$ Samfélagsmiðlafærslur sem byggja á lýsingum endurspegla pví ekki einungis sýn polenda heldur geta pær einnig endurspeglað skýringar á atburðinum. Polandinn getur pannig dregið athyglina að ákveðnum páttum, sem geta kallast á við reynslu peirra af samskiptum við gerandann og samfélagið. Efnið er mikilvægt af pví að pað varpar ljósi á sýn polenda, en einnig af pví að frásagnirnar endurspegla samfélagsleg viðhorf til kynferðisofbeldis.

\section{Aðferð}

Gögn rannsóknarinnar eru 397 íslenskar færslur sem voru settar á Facebook og Twitter frá apríl 2015 til mars 2017. ${ }^{18}$ Í gagnaöfluninni var leitað eftir færslum með leitarorðum sem tengjast ofbeldi og peirri umfjöllun sem skapaðist í kjölfar Beauty tips hreyfingarinnar: Ofbeldi, kynferðisofbeldi, \#daginneftir, \#konurtala, \#pöggun. Einungis voru valdar færslur par sem

brögð frá öðrum við frásögnum polenda (til dæmis á Twitter). Skýringar polenda í frásögnum peirra á samfélagsmiðlum eru aftur á móti nokkuð pröngt viðfangsefni og höfundi hefur ekki tekist að finna neina aðra grein par sem sú aðferð hefur verið notuð.

17 Denis Hilton, „Social Attribution and Explanation“, The Oxford Handbook of Causal Reasoning, ritstj. Michael Waldmann, Oxford: Oxford University Press, 2017. 
viðkomandi sagði frá eigin reynslu af ofbeldi. Gögnum af Twitter var safnað úr færslum í opnum aðgangi en Facebook-gögnin komu frá hópnum Beauty tips ${ }^{19}$. Flestir polendanna sem greindu frá reynslu sinni voru kvenkyns $(94,5 \%)$ og par sem kyn var tilgreint voru flestir gerendur karlkyns (97,5\%; kyn geranda var tilgreint í um $75 \%$ tilvika). ${ }^{20}$

Pessi rannsókn einkennist af stafrænni aðferðafræði (e. digital methodology), sem hefur verið leiðandi í rannsóknum á samfélagsmiðlum. Í stuttu máli felur nálgunin í sér að hinn stafræni heimur (s.s. internetið) sé framlenging á raunheiminum og lúti mörgum sömu lögmálum. Pessir heimar skarast og hafa stöðugt áhrif hvor á annan. ${ }^{21}$ Tveir aðalpættir eru sameiginlegir með raunheiminum og netheiminum pegar kemur að pessu rannsóknarefni. Í fyrra tilvikinu fela frásagnir yfirleitt í sér einhverja lýsingu á atburðinum sjálfum og áhrifum hans, óháð pví hvar frásögnin á sér stað. Í síðara tilvikinu pá hafa pær fáu fyrri rannsóknir sem eru til um petta efni sýnt að kynferðisofbeldi er skýrt með svipuðum páttum, í raunheimi (viðtöl við gerendur og spurningalistar meðal polenda) og í hinum stafræna heimi (í nafnlausum frásögnum gerenda á netinu). Pó ber að nefna að frásagnir eru ekki alltaf sambærilegar pegar kemur að pví að hverjum pær beinast. Í eigin persónu segja polendur oftast vinum eða fjölskyldu frá, en á netinu er frásögnin opinber. Polendur fá pannig tækifæri til að tjá sig um reynslu sína en einnig til að taka skýra afstöðu gegn ofbeldinu og benda á pætti sem viðkomandi finnst skipta máli. Petta rannsóknarefni er mjög nýtt og nauðsynlegt er að rannsaka pað frekar, sérstaklega hvernig frásagnir og skýringar ofbeldis hafa áhrif hvort á annað í raunheimi og í hinum stafræna heimi.

Eigindleg greining gagnanna fór fram í tveimur prepum. Fyrst var notuð bráðabirgðakóðun (e. provisional coding) ${ }^{22}$ par sem gagnasafnið var

19 Persónuvernd hefur skilgreint stóra hópa á Facebook sem opna, í ágúst 2018 voru 34.815 meðlimir í Beauty Tips hópnum. Pessi rannsókn var tilkynnt til Persónuverndar í apríl 2017. Pegar vitnað er beint í orð polenda pá var leyfi peirra fengið, ef pess reyndist nokkur kostur.

20 Frekari upplýsingar um gagnasafnið má finna í bókinni Rape in the Nordic Countries par sem fræðimenn frá öllum Norðurlöndunum skrifa kafla um nauðganir og félagslegt samhengi peirra. Bókin er væntanleg árið 2019.

21 Richard Rogers, Digital methods, Massachusetts Institute of Technology: Cambridge, MA, 2013. Hið stafræna er par af leiðandi ekki eðlisólíkt raunheiminum, heldur endurspeglar félagslegt umhverfi okkar og heimssýn. Pessi nálgun er svo notuð við pemagreiningu, sem er lýst nánar á næstu síðu.

22 Pessi nálgun við kóðun felur í sér að rannsakandi skilgreinir fyrirfram eitthvað fyrirbæri eða hugtak sem leita á að. Í pessari rannsókn var einblínt á einhvers konar 
lesið og dregin út öll tilvik par sem sett var fram einhvers konar skýring eða lýsing á ofbeldi. Вæði var leitað að tilvikum par sem viðkomandi sagði beinum orðum að eitthvað væri skýring, en einnig par sem lýsingar gáfu ákveðnar skýringar í skyn. Kosturinn við að horfa á báða flokka er sá að lýsing á atburðum getur falið í sér ákveðna eignun án pess að hún sé endilega beint orðuð sem skýring, út frá samhenginu. Pemagreining (e. thematic analysis) var svo nýtt til að flokka og skapa heildstæða mynd af skýringunum. Pemagreining felur í sér að skoða alla pá kóða sem dregnir hafa verið út úr gagnasafninu, meta hvernig peir eru líkir og ólíkir og flokka pá saman í pemu. ${ }^{23}$ Skýringarnar sem fram komu í gagnasafninu voru fjölbreyttar en greina mátti prjú meginpemu: Skýringar sem beinast að samfélaginu, að polendum og að gerendum. Hér á eftir verður fjallað um hvert pema fyrir sig og undirflokka peirra, auk pess sem niðurstöðurnar verða bornar saman við fyrri rannsóknir.

\section{Samfélagslegar skýringar}

Algengustu skýringarnar í færslum polenda sneru að samfélaginu og að pví hvernig ákveðin viðhorf stuðli að ofbeldi. Í frásögnum polenda komu fram fjórar samfélagslegar skýringar á kynferðisofbeldi: Almenn neikvæð viðhorf til kvenna, líffræðileg eðlishyggja (e. biological essentialism), réttindi (e. entitlement) og hlutgerving (e. objectification). Fyrri rannsóknir hafa sýnt að peir sem brjóta kynferðislega á öðrum eru líklegri en aðrir til að hafa neikvæð viðhorf til kvenna ${ }^{24}$ og að viðhorf dæmdra nauðgara til kvenna

skýringu ofbeldis, óháð pví hvort hún var sett fram sem eigin skýring eða annarra. Sjá meira um pessa aðferð í Johnny Saldana, The coding manual for qualitative researchers, London; SAGE, 2015.

23 Pemagreining er eigindleg rannsóknaraðferð par sem rannsakandi skoðar texta og skipuleggur merkingu hans í pemu til að skilja innihaldið. Stephanie Riger og Rannveig Sigurvinsdóttir, „Thematic Analysis“, Handbook of Methodological Approaches to Community Based Research, ritstj. Leonard Jason og David Glenwick, 2015, bls. 33-41.

24 Antonia Abbey, Pam McAuslan og Lisa Thomson Ross, „Sexual assault perpetration by college men: The role of alcohol, misperception of sexual intent, and sexual beliefs and experiences“, Fournal of Social and Clinical Psychology, 17: 2/2001, bls. 167-195; Antonia Abbey, Pam McAuslan, Tina Zawacki, Monique Clinton og Philip O. Buck, „Attitudinal, experiential, and situational predictors of sexual assault perpetration“, fournal of Interpersonal Violence, 16: 8/2001, bls. 784-807; Joetta L. Carr og Karen M. VanDeusen, „Risk factors for male sexual aggression on college campuses“, Journal of Family Violence, 19: 5/2004, bls. 279-289; Neil M. Malamuth, Daniel Linz, Christoper L. Heavey, Gordon Barnes og Michele Acker, 
eru sérstaklega neikvæð. ${ }^{25}$ Par að auki hafa svokallaðar nauðgunarmýtur (e. rape myths) verið mikið rannsakaðar, en pær fela í sér réttlætingar á ofbeldi karla gegn konum eða að lítið sé gert úr pví. Gerendur vísa gjarnan til slíkra viðhorfa til að útskýra og réttlæta hegðun sína ${ }^{26}$ en karlar eru líklegri til að nauðga ef peim finnst slík viðhorf vera ráðandi í samfélaginu. ${ }^{27}$ Neikvæð viðhorf gerenda til kvenna komu ítrekað fram í gagnasafninu. Pessi afstaða var dæmigerð fyrir lestur polenda á hegðun gerenda, sbr:

Hann kallaði mig tussu, hóru, ógeðslega, druslu... hans eign. Hann sagði mér að ég ætti ekkert gott skilið, pað myndi enginn hjálpa mér.

Hér notar gerandinn niðurlægjandi orð til að uppnefna og lítillækka polandann, sem hægt er að túlka pannig að pað bæði endurspeglar afstöðu hans og er hluti af ofbeldinu sjálfu. Í öðrum tilvikum koma fram viðhorf sem fela ekki í sér eins augljósa kvenfyrirlitningu en eru samt sem áður neikvæð, eins og til dæmis sú hugmynd að pegar konur segi nei við kynlífi pá meini pær í raun já. Pessi afstaða er gerandanum pví réttlæting á pví að brjóta á polanda, prátt fyrir mótmæli. Í gagnasafninu voru mörg dæmi um petta, en hér er eitt, par sem polandinn vitnar beint í gerandann:

„Pú veist pú vilt pað“ Já, fyrirgefðu. Takk fyrir að láta mig vita eftir að ég er búin að segja fimmtíu sinnum nei.

„Using the confluence model of sexual aggression to predict men's conflict with women: A 10-year follow-up study“, Fournal of Personality and Social Psychology, 69: 2/1995, bls. 353-369; Andra Teten Tharp, Sara DeGue, Linda Anne Valle, Kathryn A. Brookmeyer, Greta M. Massetti og Jennifer L. Matjasko, „A systematic qualitative review of risk and protective factors for sexual violence perpetration", Trauma, Violence \& Abuse, 14: 2/2013, bls. 133-167; Tina Zawacki, Antonia Abbey, Philip O. Buck, Pamela McAuslan og A. Monique Clinton-Sherrod, „Perpetrators of alcohol-involved sexual assaults: How do they differ from other sexual assault perpetrators and nonperpetrators?", Aggressive Behavior, 29: 4/2003, bls. 366380.

25 Anthony R. Beech o.fl., "The identification of sexual and violent motivations in men who assault women: Implication for treatment", bls. 1635.

26 Sama rit, bls. 1635-1653; sjá einnig Tracy N. Hipp o.fl., „Justifying sexual assault: Anonymous perpetrators speak out online“, bls. 87-89.

27 Gerd Bohner, Frank Siebler og Jurgen Schmelcher, „Social norms and the likelihood of raping: Perceived rape myth acceptance of others affects men's rape proclivity“, Personality and Social Psychology Bulletin, 32: 3/2006, bls. 286-297. 
Í fyrri rannsóknum kemur petta viðhorf, að konur segi nei við kynlífi en meini í raun já, einmitt líka fram sem skýring af hálfu peirra sem brjóta kynferðislega gagnvart öðrum. ${ }^{28}$ Sú staðreynd að polandinn nefnir pessa réttlætingu í eigin færslu endurspeglar líklega að viðhorfið hafi haft áhrif á upplifun polandans.

Með líffræðilegri eðlishyggju er átt við pað samfélagslega viðhorf að karlmenn stjórnist af eigin liffræði, til dæmis hormónum, og að peir hafi enga stjórn á kynferðislegum hvötum sínum. ${ }^{29}$ Pessi skýring hefur áður komið fram hjá gerendum en sumir peirra halda pví fram að kynhvöt peirra sé óviðráðanleg og knýi pá til að brjóta gegn öðrum. Í nafnlausum sögum gerenda á netinu er petta t.d. nefnt sem réttlæting á ofbeldishegðun. ${ }^{30}$ Í pessari rannsókn vísuðu polendur ítrekað til líffræðilegar eðlishyggju, sem afsökunar gerandans; hann hafi ekki póst geta stjórnað eigin hvötum. Hér má sjá dæmi:

Upp úr pví fóru nauðganirnar hratt fjölgandi, ég liggjandi grátandi að biðja hann um að hætta og ekki snerta mig en hann purfti að klára sitt. Kyssti mig pegar hann klárar og segir „Sorry, var bara rugl graður“.

Í pessu tilviki virðist sem gerandinn átti sig á broti sínu en telji pað léttvægt eða réttlætanlegt. Af orðum annarra gerenda má ráða að peir líti á pessar líffræðilegu hvatir sem parfir sem peir verði að fá uppfylltar:

Pegar hann loksins var búinn og losaði mig hreytti ég í hann að hann hefði verið að nauðga mér, hann svaraði „nei! petta var ekkert nauðgun, ég hætti bara að hugsa um hvað pú vildir og einbeitti mér að mínum pörfum í staðinn“.

28 R. Lance Shotland og Barbara A. Hunter, „Women's "token resistance” and compliant sexual behaviors are related to uncertain sexual intentions and rape“, Personality and Social Psychology Bulletin, 21: 3/1995, bls. 226-236, hér bls. 226; Diana Scully og Joseph Marolla, "Riding the bull at Gilley's”: Convicted rapists describe the rewards of rape“, Social Problems, 32: 3/1985, bls. 251-263, hér bls. 251.

29 Catherine A. MacKinnon, Women's lives, men's laws, Cambridge, MA: Harvard University Press, 2005, bls. 65-67.

30 Tracy N. Hipp o.fl., „Justifying sexual assault: Anonymous perpetrators speak out online", bls. 86. 
Hér virðist gerandinn telja kynlífsparfir sínar mikilvægari en vilja polandans, en pað er algengt viðhorf meðal dæmdra nauðgara. ${ }^{31}$ Gerendur taka einnig að sér að hrútskýra fyrir polandanum óumbreytanlegt eðli karla sem ekkert sé við að gera:

Hann gekk lengra prátt fyrir mótmæli mín. Ég sagði nei en hann prýsti sér inn í mig, sagði að ég myndi byrja að fýla pað eftir smástund. Ég gafst upp og lét mig hafa pað. Vildi ekki gefa honum „blue balls“ eins og hann sagði að gxti gerst ef ég riði honum ekki ... Hann kenndi mér ýmislegt um karlmenn sem hefur tekið mig mörg ár að aflæra. Hann kenndi mér að pað hvort ég vildi ríða eða ekki skipti ekki máli. Рað væri fyrir öllu að hann fengi pað. Hann sagði mér að allir karlmenn væru svona. Að ég væri bara að gera mikið úr hlutunum. Petta væri eðlilegt.

Af síðustu tveimur tilvitnunum má ráða að gerandinn sjái líffræðilegar parfir karlmanna sem sérstakar og óstjórnlegar, en einnig að karlar eigi rétt á líkömum kvenna. Hérna virðist ætlast til pess að polendur sætti sig einfaldlega við pað að ofbeldi sé eðlilegur hluti af kynlífi, karlar eigi að fá að sofa hjá, óháð pví hvað konum finnist um pað. Fáar vandaðar rannsóknir eru til um petta efni, en til dæmis sýndi ein tilraunarannsókn að pvingað skírlífi hafði ekki áhrif á líffræðileg viðbrögð karla við kynlífi. ${ }^{32}$ Greinilegt er að polandinn sjálfur hafnar pessum skýringum, en finnst mikilvægt að segja frá pví hvernig gerandinn réttlætir brot sitt. Líffræðileg eðlishyggja hefur komið sterkt fram í fyrri rannsóknum, ${ }^{33}$ en hún leiðir til misvísandi skýringa pví með henni er gefið í skyn að gerandinn geti ekki stjórnað gerðum sínum og pví ekki borið ábyrgð á brotinu. Pannig sjáum við að sé kynhvöt karla óviðráðanleg í eðli sínu pá er erfitt að draga pann til ábyrgðar sem brýtur gegn öðrum kynferðislega.

31 Anthony R. Beech o.fl., „The identification of sexual and violent motivations in men who assault women: Implication for treatment", bls. 1642.

32 Michael S. Exton, Tillmann H.C. Krüger, Norbert Bursch, Philip Haake, Wolfram Knapp, Manfred Schedlowski og Uwe Hartmann, „Endocrine response to masturbation-induced orgasm in healthy men following a 3-week sexual abstinence“, World fournal of Urology 19: 5/2001: bls. 377-382, par sem karlar voru látnir forðast kynlíf og sjálfsfróun í 3 vikur og líffræðilegar mælingar fóru fram á meðan sjálfsfróun átti sér stað. Helstu niðurstöður voru að skírlífið hafði ekki áhrif á líffræðileg viðbrögð við fullnægingu.

33 Tracy N. Hipp o.fl., ,Justifying sexual assault: Anonymous perpetrators speak out online", bls. 86 . 
Líffræðileg eðlishyggja getur líka tengst klámvæðingu, en eins og hér má sjá biðst gerandinn í raun afsökunar af pví að hann veit að hann hefur brotið á polanda:

Auðvitað fór ég í sjokk og spurði hann hvað hann væri að gera og svarið var einfaldlega „Sorry, ég er svo graður“ og svo hélt hann áfram og ég sagði honum að hætta enn svo hélt hann bara áfram og svo reyndi ég að ýta honum af mér enn pað gekk ekki... síðan hélt hann enn og aftur bara áfram og svo sagði hann: „Geturu ekki allavegana gefið frá pér svona hljóð eins og pér líki við petta ?“34

Síðasta setningin vitnar um pá kröfu að polandinn hegði sér á ákveðinn hátt til að póknast gerandanum meðan brotið á sér stað, ef til vill til að líkja eftir klámi. Polandinn á að láta eins og viðkomandi líki petta, pótt báðir aðilar viti að svo er ekki. Líffræðileg eðlishyggja og klám hafa einnig birst í listaverkum og fjölmiðlum, til dæmis má sjá teikningu eftir Hugleik Dagsson ${ }^{35}$ hér fyrir neðan sem endurspeglar síðustu tilvitnun vel.

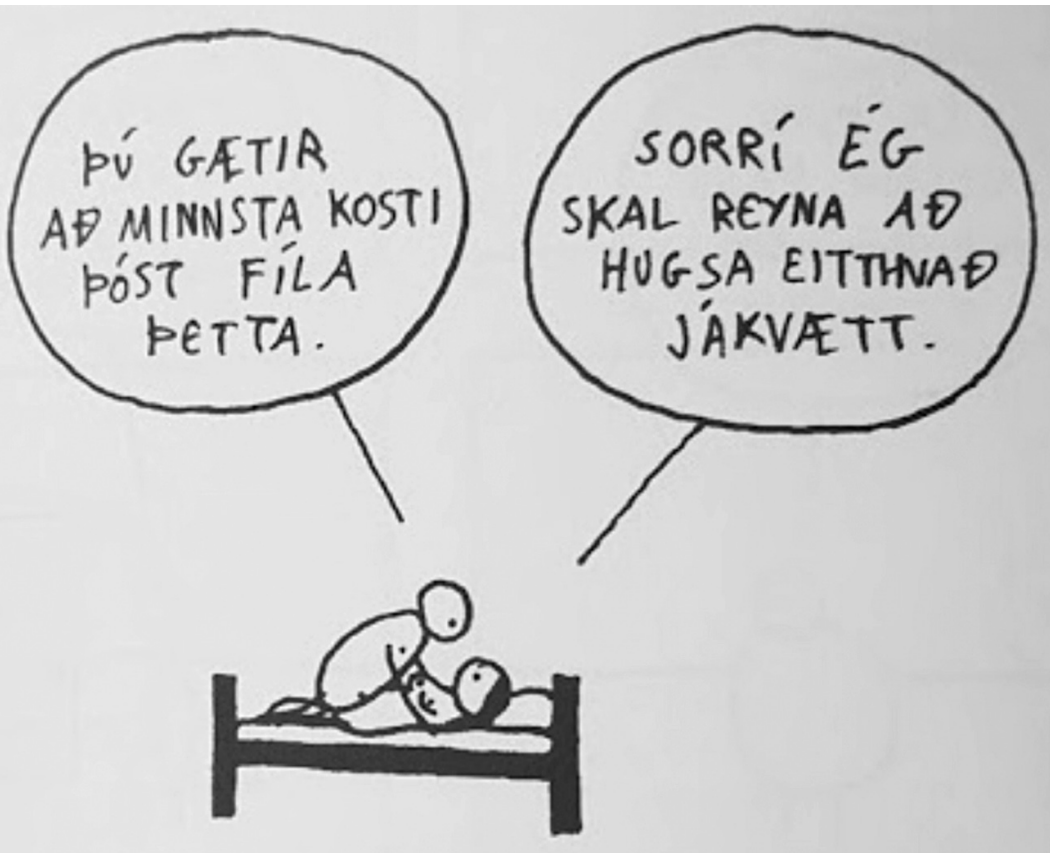

34 Petta er ein af tveimur tilvitnunum greinarinnar sem kemur frá karlmanni, en hún sýnir að polendur geta einnig verið karlkyns og orðið fyrir áhrifum samfélagslegra hugmynda um kynferðisofbeldi og klám.

35 Hugleikur Dagsson, Hvað með börnin?, Reykjavík: Forlagið, 2015, bls. 44. 
Bæði í teikningunni og í tilvitnuninni á polandinn ekki bara að pola ofbeldið, heldur líka að láta eins og hann sé sampykkur pví. Samhengið er vissulega ólíkt, par sem Hugleikur Dagsson setur petta fram sem grín og viðhorf persónunnar í myndasögunni er líklega ekki hans sjálfs. Мeð pví að setja dæmið upp á pennan hátt er Hugleikur að gagnrýna nauðgunarmýtur og draga fram hversu fáránlegar pessar aðstæður eru. Раð að Hugleikur og gerandinn í tilvitnuninni segi næstum orðrétt sama hlutinn getur mögulega endurspeglað hversu sterk pessi samfélagslega hugmynd er. Í einni færslunni er fjallað beinum orðum um að samfélagið eigi stóran pátt í að kalla fram ofbeldi með pví að tengja kynlíf við niðurlægingu kvenna:

Раð er eitthvað verulega brenglað í samfélaginu okkar sem segir ótrúlegum fjölda stráka og karla að ofbeldi sé eðlileg hegðun. Og ótrúlega sick að svona margir karlar fái kynferðislegt kick út úr niðurlægingu. Ég skil pað ekki en ég trúi pví að pað geti breyst. Рað verður að breytast!

Réttindaskýringar (e. entitlement) felast í bví að karlar telja sig eiga rétt á konum, sérstaklega pegar kemur að kynlífi. Til dæmis finnst dæmdum nauðgurum að kynferðislegar parfir peirra séu mikilvægari en annarra. ${ }^{36}$ Réttindaskýringar eru algengar en til dæmis finnst mörgum eiginmönnum og kærustum að peir eigi rétt á kynlífi frá maka sínum. Pessar hugmyndir eru svo rótgrónar að í réttarkerfi Bandaríkjanna má finna mörg dæmi pess að eiginmenn séu ekki dæmdir fyrir að nauðga konum sínum. ${ }^{37}$ Á Íslandi fengu slík viðhorf stoð í lögum og í sifjarétti pótti vera fyrir hendi svonefnd jákvæð hjúskaparskylda (lat. debitum conjugale eða carnale), par sem skylt er að leggjast með maka sínum. Dæmi eru um að í Danmörku á 18. öld hafi verið reynt að pvinga fólk til pessa með refsiviðurlögum, en ekki er vitað til að slíkt hafi verið gert á Íslandi, en allt par til núgildandi hjúskaparlög tóku gildi 1. júlí 1993 gat „synjun annars maka á kynmökum

36 Anthony R. Beech o.fl., "The identification of sexual and violent motivations in men who assault women: Implication for treatment", bls. 1642.

37 Walter S. DeKeseredy, McKenzie Rogness og Martin D. Schwartz, „Separation/ divorce sexual assault: The current state of social scientific knowledge“, Aggression and Violent Behavior, 9: 6/2004, bls. 675-691. Petta efni hefur ekki verið rannsakað sérstaklega í íslenskum dómum en pað væri áhugavert að sjá hvort svipaðar niðurstöður kæmu fram. 
án gildra ástæðna verið skilnaðarsök““ ${ }^{38}$ Í pessari rannsókn komu réttindaskýringar fram hjá polendum, bæði varðandi hegðun gerandans og viðhorf samfélagsins:

Ég vildi að stráknum sem nauðgaði mér hefði ekki verið kennt að hann ætti pað inni hjá mér að ég myndi sofa hjá honum.

Hér sést mjög skýrt að polandinn telur samfélagið og viðhorf sem strákum séu kennd vera stóran orsakapátt í ofbeldinu. Í ástarsamböndum geta slíkar hugmyndir um réttindi einnig komið við sögu, p.e. að konum sé skylt að veita maka sínum kynlíf:

„Ef ég fæ ekki að ríða pér, pá er ég hættur með pér.“ Ég veit ekki hversu oft pessi setning hefur spilast í hausnum á mér og mér hefur langað að fara aftur í tímann og knúsa brotnuðu litlu mig og segja að ég eigi að standa með sjálfri mér.

Hér setur polandinn fram réttindaskýringu í peim skýra tilgangi að hafna henni. Réttindaskýringar má sjá vîða í samfélaginu, til dæmis meðal hóps sem nefnir sig ,incels“ og segist stunda skírlífi gegn vilja sínum (e. involuntarily celibate). Meðlimi hans má finna víða um heim en peir álíta að karlar eigi rétt á kynlífi og að pað sé óréttlátt ef konur vilji ekki stunda kynlíf með peim. Viðbrögð peirra við meintu óréttlæti eru hatur og ofbeldi, en nýlega hafa einstaklingar sem kenna sig við pessa hreyfingu gerst sekir um hryðjuverk..$^{39}$ Réttindaskýringar eru pví hættulegar vegna pess að pær eru notaðar til að réttlæta yfirstaðið ofbeldi og pað sem meira er, pær geta einnig stuðlað að frekara ofbeldi seinna meir, líkt og aðrar ranghugmyndir sem eru notaðar til að réttlæta ofbeldi.

Síðasta samfélagslega skýringin er hlutgerving, en hún felur í sér að fólk er metið út frá útliti og notagildi fyrir aðra. Рað á sérstaklega við um konur, sem pá eru metnar eftir pví hvernig líkamar peirra geta nýst til

38 Ármann Snævarr, Sifjaréttur II (4. útgáfa), Reykjavík: Háskólaútgáfan, 1988, bls. 351.

39 Alek Minassian drap 10 manns í apríl 2018 í Toronto, Kanada, og Elliot Rodger drap 6 manns í maí 2014 í Kaliforníu, Bandaríkjunum, en báðir kenndu sig við Incel hreyfinguna. Sjá Robin Abcaria, „The idea of an incel rebellion would be laughable if it hadn't already resulted in so many murders“, Los Angeles Times, 8. maí 2018, sótt 12. júní 2018 af http://www.latimes.com/local/abcarian/la-me-abcarian-incels-20180508-story.html. 
að pjónusta karla og uppfylla parfir peirra. ${ }^{40}$ Viðhorf sem einkennast af hlutgervingu kvenna koma til dæmis fram hjá körlum sem gefa konum einkunnir fyrir útlit sitt, uppnefna pær og leggja áherslu á notagildi líkama peirra fyrir pá sjálfa. ${ }^{41}$ Almennt eru peir sem hlutgera aðra líklegri til að kenna polendum fremur en gerendum um ofbeldi og gera lítið úr pjáningu hinna fyrrnefndu. ${ }^{42}$

Sumir polendanna í rannsókninni lýstu pví að peir hefðu sjálfir verið farnir að upplifa eigin líkama sem hlut, og að pað hefði haft áhrif á hegðun peirra og e.t.v. átt pátt í pví að ofbeldið átti sér stað:

Ég trúði pví í raun og veru að virði mitt lægi í líkama mínum og hvernig aðrir sæju hann og nytu hans. Pað tók fjölmörg ár fyrir mig að læra að kynlíf er eitthvað sem maður nýtur MEĐ öðrum, ekki eitthvað sem gert er FYRIR aðra.

Til dæmis hefur hugtakið eigin ögun (e. normalization) verið notað til að skýra pað hvernig polendur ofbeldis aðlagast að ofbeldinu og hugmyndum tengdum pví. Orðræða um fyrirbæri getur haft mikil áhrif á viðhorf fólks, jafnvel á pann hátt að viðkomandi fer að haga eigin hegðun í takt við pað. Petta kemur svo ekki upp á yfirborðið fyrr en einhver hefur beinlínis boðið pessari hugmynd birginn. ${ }^{43}$ Mögulega endurspeglar pessi afstaða, að hafna hlutgervingunni, aukna umræðu og hugarfarsbreytingu í samfélaginu um kynferðislegt ofbeldi, p.e.a.s. að polendur sjá eigin upplifun í nýju ljósi. Par að auki sýna færslurnar að hegðun gerenda endurspeglar hvernig polandinn er hlutgerður:

40 Barbara L. Fredrickson og Tomi-Ann Roberts, „Objectification theory: Toward understanding women's lived experiences and mental health risks“, Psychology of Women Quarterly, 21: 2/1997, bls. 173-206.

41 Tracy N. Hipp o.fl., ,Justifying sexual assault: Anonymous perpetrators speak out online“, bls. 86-87.

42 Steve Loughnan, Afroditi Pina, Eduardo Vasquez og Elisa Puvia, „Sexual objectification increases rape victim blame and decreases perceived suffering“, Psychology of Women Quarterly, 37: 4/2013, bls. 455-461, hér bls. 455; Philippe Bernard, Steve Loughnan, Cynthie Marchal, Audrey Godart og Olivier Klein, „The exonerating effect of sexual objectification: Sexual objectification decreases rapist blame in a stranger rape context“, Sex Roles, 72: 11-12/2015, bls. 499-508, hér bls. 499.

43 Ingólfur Ásgeir Jóhannesson, „Leitað að mótsögnum“, Fötlun: Hugmyndir og aðferðir á nýju freðasviði, ritstj. Rannveig Traustadóttir, Reykjavík: Háskólaútgáfan, 2006. 
Yfir pennan tíma sem nauðgunin tók skellti hann mér í hvað sem honum sýndist og kom fram við mig eins og dauðan hlut eða kynlífsdúkku.

Hlutgerving getur einnig tengst öðrum samfélagslegum skýringum, t.d. pannig að ef konur eru hlutir pá hafi karlar eignarhald yfir peim og megi koma fram við pær eins og peir vilja. Samfélagsskýringarnar sem koma fram í færslum polenda eru blandaðar, en lýsa að mestu leyti pví hvernig polendur lesa í hegðun gerenda og í samfélagið sjálft. Pær lýsingar og skýringar sem koma hér fram geta endurspeglað hvaða áhrif samfélagsleg viðhorf hafa á ofbeldi.

\section{Skýringar sem snúa að polendum}

Skýringar á ofbeldi sem snúa að polanda pess hafa verið rannsakaðar, bæði frá sjónarhóli polenda og gerenda. ${ }^{44}$ Hér verður fjallað um tvær slíkar skýringar, viðnám brotapola og áfengisneyslu hans. Fyrri rannsóknir sýna að gerendur, samfélagið og jafnvel réttarkerfið búist við pví að sá sem verður fyrir kynferðisofbeldi veiti ákveðið viðnám til pess að fullyrða megi að um ofbeldi hafi verið að ræða (en ekki kynlíf með sampykki beggja). Gerendur hafa réttlætt ofbeldi með pví að polandinn hafi ekki sagt nei, hafi ekki sagt nei nógu skýrt eða jafnvel ekki barist nógu mikið um til pess að stöðva verknaðinn. ${ }^{45}$ Viðnámið virðist líka gegna lykilhlutverki í upplifun polendanna sjálfra, oft kenna peir sjálfum sér um ef peir veittu ekki viðnám, en ef peir börðust og ofbeldi átti sér samt sem áður stað kenna peir gjarnan samfélaginu um nauðgunina. ${ }^{46}$ Í færslunum sem skoðaðar voru fjalla polendur m.a. um viðbrögð sín og viðnám í aðstæðunum til að útskýra ofbeldið:

Pegar mér var nauðgað sagði ég ekki orðið 'nei', heldur bað hann um að hætta og sagðist langa að fara heim en hann hætti ekki og ég fraus. Mér leið eins og ég ætti ekki skilið neina hjálp eftir á vegna pess að ég barðist ekki nógu vel á móti honum. En ég veit í dag að pað er ekki rétt.

44 Sapanda D. Donde, „College women's attributions of blame for experiences of sexual assault“, bls. 3520-3538; Tracy N. Hipp o.fl., „Justifying sexual assault: Anonymous perpetrators speak out online“, bls. 82-90.

45 Sama heimild, bls. 85-86; Carin Perilloux, Joshua D. Duntley og David M. Buss, „Blame attribution in sexual victimization“, bls. 81-86.

46 Sapanda D. Donde, „College women's attributions of blame for experiences of sexual assault", bls. 3531-2. 
Polendur nefna að aðrir ætlist til pess að peir komi í veg fyrir nauðgun með pví að berjast gegn henni:

Í mörg ár hélt ég að petta væri ekki nauðgun, bví ég man ekki eftir að hafa barist á móti. Ég man ekki eftir að hafa sagt nei, reyndar man ég ekki eftir að hafa hreyft mig allan tímann. Svo lærði ég í fyrra að petta kallast víst að frjósa. Ég er frjáls í dag frá pessu, enda veit ég að petta var ekki mér að kenna.

Einnig kemur fyrir að aðrir, sem ekki áttu hlut að máli, kenna polendum um ofbeldið:

Sagði kennara frá pví sem gerðist en hann sagði mér að pað væri mér að kenna að ég var ekki nógu „clear“ pegar ég sagði „hættu“ eða „ég vil petta ekki“ svo ég hætti að reyna segja fólki.

Pessi skýring, að polandinn eigi að hindra ofbeldið, tengist einnig líffræðilegri eðlishyggju sem gerir ráð fyrir að karlar ráði ekki við kynhvöt sína og að pað sé pví á ábyrgð polandans að stöðva gerandann. Petta er nátengt peirri tilhneigingu að kenna polendum um ofbeldi, sem virðist nokkuð sterk meðal almennings í spurningakönnunum ${ }^{47}$ og jafnvel pegar petta efni er skoðað sérstaklega á samfélagsmiðlum. ${ }^{48}$

Önnur polendaskýring er áfengisneysla, en polendum er iðulega kennt um ofbeldi ef peir voru undir áhrifum áfengis pegar glæpurinn var framinn. Pessi skýring kemur fram hjá polendum sjálfum, ${ }^{49}$ hjá gerendum ${ }^{50} \mathrm{og}$ meðal almennings. ${ }^{51}$ Í færslunum sem kannaðar voru var nokkuð algengt

47 Enrique Gracia, „Intimate partner violence against women and victim-blaming attitudes among Europeans“, Bulletin of the World Health Organization, 92: 5/2014, bls. 380-381.

48 Megan Stubbs-Richardson, Nicole E. Rader og Arthur G. Cosby, „Tweeting rape culture: Examining portrayals of victim blaming in discussions of sexual assault cases on Twitter", Feminism and Psychology 28: 1/2018, bls. 90-108. Par kemur fram að Twitter notendur sem birta staðhæfingar par sem polendum er kennt um ofbeldi eru líklegri til að hafa fleiri fylgjendur og vera deilt oftar (e. retweeted).

49 Carin Perilloux, Joshua D. Duntley og David M. Buss, „Blame attribution in sexual victimization“, bls. 85 .

50 Tracy N. Hipp o.fl., „Justifying sexual assault: Anonymous perpetrators speak out online“, bls. 85 .

51 Amy Grubb og Emily Turner, „Attribution of blame in rape cases: A review of the impact of rape myth acceptance, gender role conformity and substance use on victim blaming“, Aggression and Violent Behavior, 17: 5/2012, bls. 443-452, hér bls. 443 . 
að áfengisneysla polandans væri dregin fram sem skýring á ofbeldinu, oftast af polendunum sjálfum. Pá var ölvunin stundum sögð hafa hindrað polandann í að koma í veg fyrir ofbeldið eða hafa gert hann varnarlausan gagnvart gerandanum. Sumir polendur lýsa pví að ofbeldið hafi átt sér stað vegna áfengisneyslu peirra. Hér getur skömm vegna eigin neyslu einnig átt hlut að máli:

Ég vildi að mér liði ekki eins og petta væri mér að kenna af pví ég var svo drukkin.

Í sumum færslum vekja polendur athygli á pví hversu slæm pessi viðhorf eru og hafna peim beinlínis:

Ég hefði ekki átt að vera að drekka. Ég hefði ekki átt að piggja pennan bjór. Bullshit. Hann hefði ekki átt að byrla mér. ${ }^{52}$

Hérna setur polandinn fram pessa sterku samfélagslegu hugmynd að ofbeldi sé sök polanda sem er undir áhrifum áfengis til pess að benda markvisst á hana og andmæla henni.

\section{Skýringar sem snúa að gerendum}

Pær rannsóknir sem byggjast á sýn gerenda hafa sjaldnast lagt mikla áherslu á bá sjálfa sem skýringu ofbeldis. Slíkt kemur varla á óvart par sem fólk er líklegra til að skýra eigin hegðun með vísan í aðstæður, en hegðun annarra með vísan í persónulega eiginleika peirra sjálfra. ${ }^{53}$ Meðal polenda kom sú skýring fram að gerandinn sé vondur, til dæmis segir einn peirra að gerandinn sé að leita að næstu beit, líkt og um dýr sé að ræða:

Mér líður bara ílla og finn fyrir vissu óöryggi og kvíða að vita af svona mönnum á vappinu. Frjálsir sem fuglar í leit að næstu beit.

Rannsóknir á staðalímyndum gerenda kynferðisofbeldis í Bandaríkjunum hafa sýnt að mjög algengt er að almenningur sjái pennan hóp sem rándýr

52 Önnur tilvitnun frá karlmanni, sem sýnir að karlmenn geta einnig upplifað neikvætt samfélagslegar hugmyndir um áfengisneyslu polanda pegar kemur að kynferðisofbeldi.

53 Lee Ross, „The intuitive psychologist and his shortcomings: Distortions in the attribution process“, Advances in Experimental Social Psychology, 10/1977, bls. 173220. 
sem brjóti gegn ókunnugum, gera pað vegna eigin skorts á siðferði og að peir munu hegða sér svona, sama hvað að er gert. ${ }^{54}$ Að einhverju leyti mætti líka tengja pessa tilvitnun líffræðilegri eðlishyggju, par sem rándýr eru að fylgja eigin eðli með pví að ráðast á aðra. Aðrir polendur taka sérstaklega fram að gerandinn passi ekki inn í pá staðalímynd að gerandinn sé rándýr, en pað geri brotið gegn peim ekkert minna. Petta getur m.a. haft áhrif á pað hvort polendum finnist að peir geti sagt frá:

Mér leið illa með að segja frá af pví að sá sem nauðgaði mér er ekki skrímsli né ógeð sem á að skera undan.

Staðreyndin er sú að gerendur kynferðisofbeldis er fjölbreyttur hópur. ${ }^{55}$ Töluvert hefur verið rætt um petta efni síðustu ár í íslensku samfélagi, til dæmis með tilkomu Druslugöngunnar og vinnu samtaka eins og Blátt áfram og Stígamóta. ${ }^{56}$

\section{Lokaorð}

Skýringarnar sem koma fram í færslum af samfélagsmiðlunum eru að hluta til af samfélagslegum toga og vísa í ýmsar hugmyndir um konur, karla og samskipti kynjanna. Pær samanstanda af almennum neikvæðum viðhorfum til kvenna, líffræðilegri efnishyggju, réttindum karla til kynlífs og hlutgervingu.

Segja má að margar skýringanna sem koma fram í færslunum tengist að einhverju leyti innbyrðis. Pannig tengist líffræðileg eðlishyggja hugmyndum um réttindi, p.e. að kynhvöt karla sé ekki bara sterk og óstjórnleg, heldur eigi peir líka rétt á að fá hana uppfyllta, eins og fyrri rannsóknir

54 Justin T. Pickett, Christina Mancini og Daniel P. Mears, „Vulnerable victims, monstrous offenders, and unmanageable risk: Explaining public opinion on the social control of sex crime“, Criminology 51: 3/2013, bls. 729-759. Íslenskar rannsóknir um petta efni hafa ekki birst í ritrýndum tímaritum, en slík pekking væri mjög pörf.

55 Elísabet Karlsdóttir og Ásdís A. Arnalds, „Rannsókn á ofbeldi gegn konum: Reynsla kvenna á aldrinum 18-80 ára á Íslandi“, Stjórnarrádið, desember 2010, sótt 29. apríl 2018 af https://www.stjornarradid.is/media/velferdarraduneyti-media/media/ ritogskyrslur2011/26012011_Ofbeldi_a_konum.pdf, hér bls. 51-52.

56 Sjá til dæmis Guðrún Jónsdóttir, „Surviving incest“, Fournal of Social Work Practice, 4: 3-4/1990, bls. 56-70. Samtökin Blátt áfram voru stofnuð árið 2004 og á vegum peirra hefur verið haldinn fjöldi fyrirlestra og námskeiða um kynferðisofbeldi gegn börnum (www.blattafram.is). Samtökin Stígamót (www.stigamot.is) voru stofnuð árið 1989 en starfsfólk pess veitir ráðgjöf og fræðslu um kynferðisofbeldi. 
hafa gefið til kynna. ${ }^{57}$ Ekki nóg með pað, heldur er einnig ætlast til pess að konur berjist líkamlega gegn körlum, annars sé ekki um nauðgun að ræða. Skýringar gerendanna á kynferðisofbeldi virðast flestar miða að pví að taka ábyrgðina af peim (peir ráði ekki við sig eða eigi rétt á pessu) og að kenna polendum um (vegna skorts á viðnámi eða áfengisneyslu). Рað er pví mikilvægt að uppfræða ungt fólk og samfélagið í heild um pessi viðhorf og vinna markvisst gegn peim, vegna pess að pau geta haft alvarlegar afleiðingar, s.s. frekara ofbeldi og skömm.

Í frásögnum polendanna í pessari rannsókn koma fram mörg af sömu pemum og í fyrri rannsóknum á viðhorfum gerenda. ${ }^{58}$ Eitt af pví sem einkennir skýringarnar í færslunum er að par setja polendurnir fram ákveðin viðhorf í peim tilgangi að andmæla peim. Petta á bæði við um viðhorf annarra og eldri viðhorf polendanna sjálfra sem peir hafa snúið baki við. Dæmi um petta er hugmyndin um að áfengisneysla polandans sé orsök ofbeldisins. Pessi aðferð, að setja fram skýringu gagngert til að hafna henni, er ein leið polendanna til pess að benda á og vinna gegn skaðlegum ranghugmyndum. Polendur geta pví notað samfélagsmiðla til pess að hafna eigin ábyrgð á ofbeldinu, sem áður hafði verið lögð á pá. Að setja fram eigin sögu á pennan hátt er mikilvægur páttur í baráttunni gegn kynferðislegu ofbeldi.

Pessi rannsókn hefur ákveðnar takmarkanir. Í fyrsta lagi miðast gögnin og greiningarnar við færslur sem voru settar fram á samfélagsmiðlum á ákveðnu tímabili. Auðvitað er mögulegt að í gagnasafnið vanti einhverjar færslur sem lúta að skýringum polenda á kynferðisofbeldi. Pað er pví ekki hægt að fullyrða að gögnin endurspegli viðhorf allra polenda. Færslurnar miðast líka við upplifun polenda, pó peir lesi gjarnan í hegðun annarra. Beinar skýringar á ofbeldi komu aðeins fram í sumum færslum og mikið af skýringum voru túlkanir á lýsingum polenda. Eftir sem áđur er hér um að ræða fyrstu rannsóknina sem skoðar viðfangsefnið með pessari aðferðafræði og veitir mikilvæga innsýn inn í málefnið.

Kynferðisofbeldi er alvarlegt efni og skýringar á pví varpa ljósi á samfélagslegt samhengi pess. Forvarnir og viðbrögð við ofbeldi purfa að taka mið af pví að ofbeldi er ekki einangrað vandamál heldur tengist öðrum

57 Anthony R. Beech o.fl., "The identification of sexual and violent motivations in men who assault women: Implication for treatment", bls. 1642.

58 Tracy N. Hipp o. fl., „Justifying sexual assault: Anonymous perpetrators speak out online“, bls. 82-90. 
skaðlegum páttum eins og neikvæðum viðhorfum til kvenna og íhaldssömum skoðunum um samskipti kynjanna. Frekari rannsóknir á pessu efni eru nauðsynlegar til að skilja betur skýringar á ofbeldi. ${ }^{59}$

\section{ÚTDRÁTTUR}

\section{„Pú veist pú vilt pað““ \\ Skýringar á kynferðisofbeldi á samfélagsmiðlum}

Skýringar á kynferðisofbeldi eru mikilvægt rannsóknarefni pví pær varpa ljósi á samfélagslegt samhengi ofbeldisins. Fyrri rannsóknir sýna að algengt er að gerendur skorist undan ábyrgð á ofbeldinu, og vísi frekar í polandann eða sjálfar aðstæðurnar sem áhrifapætti. Í pessari rannsókn voru 397 íslenskar færslur polenda af samfélagsmiðlunum Facebook og Twitter greindar með tilliti til pess hvernig ofbeldi var skýrt. Skýringarnar voru prennskonar. Í fyrsta lagi pær sem sneru að samfélaginu en pær fólu til dæmis í sér skírskotun til almennra neikvæðra viðhorfa til kvenna, líffræðilegrar eðlishyggju (p.e. að karlar ráði ekki við kynhoöt sína), réttinda karla til kynlífs og til hlutgervingar. Í öðru lagi voru pað polendaskýringar sem fjölluðu um áfengisneyslu peirra og að viðnám peirra væri nauðsynlegt svo skilgreina mætti atvikið sem ofbeldi. Að lokum voru pað gerendaskýringar sem mörkuðust af skrímslavæðingu, p.e. ýmist var talið að gerendur væru vondir eða peir féllu ekki að slíkri staðalímynd. Niðurstöður rannsóknarinnar sýna að pegar kemur að kynferðisofbeldi eru sterkar samfélagslegar staðalímyndir lífseigar og pví er mikilvægt að vinna gegn peim í framtíðinni.

Lykilorð: Kynferðisofbeldi, samfélagsmiðlar, skýringar

\section{A B S T R ACT}

\section{„You know you want it“" Social media explanations of sexual violence}

Explanations of sexual violence are an important topic because they reveal the societal context of violence. Perpetrators of violence commonly reject blame, explaining their actions with survivor behavior or the situation. In this study, 397 Icelandic

59 Höfundur vinnur nú að stórri rannsókn um frásagnir polenda kynferðisofbeldis á samfélagsmiðlum sem hefur verið styrkt af Rannís. Höfundur vill pakka öllum peim hugrökku polendum sem sögðu sögu sína og sérstaklega peim sem leyfðu að vitnað væri beint í pá í pessari grein. 
social media posts from Facebook and Twitter were analyzed for explanations of violence. Societal explanations included general negative attitudes towards women, biological essentialism (that men cannot control their sex drive), the entitlement of men to sex and objectification. Survivor explanations included that the survivor had been drinking alcohol at the time of the violence, and that the survivor was expected to fight back to justify the event being classified as violence. The monster stereotype of perpetrators was salient in the accounts, either as fact, or to specifically challenge that idea. The results reveal powerful societal stereotypes when it comes to sexual violence, which need to be counteracted in the future.

Keywords: Sexual violence, social media, explanations

\section{Rannveig Sigurvinsdóttir}

Lektor í sálfræði

Háskólinn í Reykjavík

rannveigs@ru.is 